\title{
Endoscopic Ultrasound-Guided Fine Needle Aspiration and Endoscopic Retrograde Cholangiopancreatography-Based Tissue Sampling in Suspected Malignant Biliary Strictures: A Meta-Analysis of Same-Session Procedures
}

\author{
Diogo Turiani Hourneax de Moura ${ }^{1,2}$, Marvin Ryou' ${ }^{1}$ Eduardo Guimarães Hourneaux de Moura ${ }^{2}$, Igor Braga Ribeiro², \\ Wanderlei Marques Bernardo ${ }^{2}$ and Christopher C. Thompson ${ }^{1}$ \\ 1Division of Gastroenterology, Hepatology and Endoscopy, Brigham and Women's Hospital, Harvard Medical School, Boston, MA, USA, \\ ${ }^{2}$ Endoscopy Unit, Department of Gastroenterology, Hospital das Clínicas da Faculdade de Medicina da Universidade de São Paulo, Brazil
}

Background/Aims: The diagnosis of biliary strictures can be challenging. There are no systematic reviews studying same-session endoscopic retrograde cholangiopancreatography (ERCP)-based tissue sampling and endoscopic ultrasound-guided fine needle aspiration (EUS-FNA) for the diagnosis of biliary strictures.

Methods: A systematic review was conducted on studies analyzing same-session EUS and ERCP for tissue diagnosis of suspected malignant biliary strictures. The primary outcome was the accuracy of each method individually compared to the two methods combined. The secondary outcome was the accuracy of each method in pancreatic and biliary etiologies. In the meta-analysis, we used Forest plots, summary receiver operating characteristic curves, and estimates of the area under the curve for intention-to-treat analysis. Results: Of the 12,132 articles identified, six were included, resulting in a total of 497 patients analyzed. The sensitivity, specificity, positive likelihood ratio, negative likelihood ratio, and accuracy of the association between the two methods were: $86 \%, 98 \%, 12.50$, 0.17 , and $96.5 \%$, respectively. For the individual analysis, the sensitivity, specificity and accuracy of EUS-FNA were $76 \%, 100 \%$, and 94.5\%, respectively; for ERCP-based tissue sampling, the sensitivity, specificity, and accuracy were 58\%, $98 \%$, and $78.1 \%$, respectively. For pancreatic lesions, EUS-FNA was superior to ERCP-based tissue sampling. However, for biliary lesions, both methods had similar sensitivities.

Conclusions: Same-session EUS-FNA and ERCP-based tissue sampling is superior to either method alone in the diagnosis of suspected malignant biliary strictures. Considering these results, combination sampling should be performed when possible. Clin Endosc 2020;53:417-428

Key Words: Cancer; Diagnosis; Endoscopic retrograde cholangiopancreatography; Endoscopic ultrasound; Endoscopy

\section{INTRODUCTION}

Biliary strictures can be challenging, both in terms of their

\section{Received: February 21, 2019 Revised: March 30, 2019}

Accepted: April 25, 2019

Correspondence: Christopher C. Thompson

Division of Gastroenterology, Hepatology and Endoscopy, Brigham and Women's Hospital, Harvard Medical School, 75 Francis St., Thorn 1404 Boston, MA 02115, USA

Tel: +1-617-525-8266, Fax: +1-617-264-6342, E-mail: cthompson@hms.harvard. edu

ORCID: https://orcid.org/0000-0002-6105-5270

(cc) This is an Open Access article distributed under the terms of the Creative Commons Attribution Non-Commercial License (http://creativecommons.org/ licenses/by-nc/3.0) which permits unrestricted non-commercial use, distribution, and reproduction in any medium, provided the original work is properly cited. diagnosis and in terms of their treatment (both curative and palliative). ${ }^{1,2}$ Establishing a tissue diagnosis of malignancy before surgery is an important step when evaluating patients with a suspected malignant biliary stricture. ${ }^{3}$ However, most patients presenting with obstructive symptoms are not candidates for surgery, either owing to locally invasive or metastatic cancer. ${ }^{4,5}$ Only $10 \%$ to $15 \%$ of pancreatic cancers and $20 \%$ to $49 \%$ of cholangiocarcinomas (CCAs) are resectable. For patients for whom palliative therapy is indicated, chemotherapy or radiotherapy requires a definitive histological diagnosis. ${ }^{6-8}$ Currently, two methods are most widely available for the pathological diagnosis of a suspected malignant biliary stricture: endoscopic retrograde cholangiopancreatography (ER$\mathrm{CP})$-based tissue sampling and endoscopic ultrasound-guided 
fine needle aspiration (EUS-FNA), ${ }^{3,9}$

ERCP-based tissue sampling methods include biliary brush cytology (BC) and intraductal forceps biopsy (FB), with sensitivities ranging from $30 \%$ to $78 \%$ for $\mathrm{BC}^{10-13}$ and from $29 \%$ to $81 \%$ for $\mathrm{FB},{ }^{10,14-18}$ with higher yields usually found when both methods are combined. ${ }^{1,2,5}$ As expected, ERCP-based tissue sampling produces better results for intraductal compared to extraductal lesions. A recent study showed an accuracy of $82.4 \%$ for intraductal lesions compared to $54.8 \%$ for extraductal lesions. ${ }^{2}$

EUS-FNA allows for complete visualization of the pancreas and adjacent organs, and therefore targeted tissue acquision. ${ }^{19-21}$ EUS-FNA is considered by most to be the gold-standard technique for pancreatic masses, which are the most common cause of malignant biliary strictures. ${ }^{22,23}$ Additionally, a recent systematic review and meta-analysis demonstrated that the pooled sensitivity and specificity of EUS-FNA for malignant biliary obstructions were $75 \%$ and $100 \%$, respectively. ${ }^{24}$ This satisfactory yield is achievable in the absence of an identifiable mass on previous imaging ${ }^{25}$ and in the setting of suspected CCA with sensitivity ranging from $73 \%$ to $89 \%$. ${ }^{26-29}$

Even though EUS-FNA and ERCP-based tissue sampling have been compared extensively in the diagnosis of biliary strictures, few studies have evaluated the combination of these methods in same-session procedures in comparison to either modality alone. Therefore, the aim of this analysis was to evaluate the performance of EUS-FNA and ERCP-based tissue sampling in same-session procedures, and to identify an optimal tissue acquisition strategy for suspected malignant biliary strictures.

\section{MATERIALS AND METHODS}

\section{Protocol and registration}

This systematic review and meta-analysis was conducted following the Preferred Reporting Items for Systematic Reviews and Meta-Analyses (PRISMA) recommendations. ${ }^{30}$ The review was registered in PROSPERO international database (CRD42019119042) and can be accessed at http://www.crd. york.ac.uk/PROSPERO.

\section{Eligibility criteria}

Clinical trials and observational studies were evaluated; case reports and abstracts were not eligible. Patients with a suspected malignant biliary stricture (without cytohistological diagnosis) who underwent same-session EUS-FNA and ERCP-based tissue sampling were included. Additionally, a "gold-standard" comparison procedure (i.e., surgical histology or tissue sampling) with a six-month follow-up period was required for inclusion. The main outcome was the accuracy of ERCP-based tissue sampling and EUS-FNA in the diagnosis of suspected malignant biliary strictures. Secondary outcomes included the accuracy of each diagnostic method in specific pancreatic and biliary etiologies. Also, a comparison between $\mathrm{FB}$ and $\mathrm{BC}$ was performed. Outcome measures included sensitivity, specificity, positive likelihood ratio (+LR), negative likelihood ratio (-LR), and area under the curve (AUC).

\section{Search}

The following search strategy was used in the Medline database: (cholangiocarcinoma OR bile duct neoplasms OR biliary stricture OR pancreatic cancer OR pancreatic mass OR ampullary cancer OR biliary stenosis OR chronic pancreatitis OR adenocarcinoma OR gallbladder cancer OR bile duct cancer OR biliary tumor OR Klatskin tumor) AND (EUS OR endoscopic ultrasonography OR echoendoscopy OR FNA OR fine needle aspiration OR FNB OR fine needle biopsy) AND (ERCP OR endoscopic retrograde cholangiopancreatography OR biopsy OR brush OR cytology). In the EMBASE, Cochrane, LILACS, Scopus, and CINAHL databases, the search was summarized into "biliary stricture and ERCP and endoscopic ultrasound." The last search was performed on $02 /$ January/2019.

\section{Study selection}

The articles were selected after an initial assessment of the titles and abstracts in order to assess the relevancy of the full text. The selection was performed by three independent reviewers. Disagreements between the reviewers were resolved via a discussion with all authors. To summarize the study selection processes, an adapted PRISMA flow diagram was used (Fig. 1). ${ }^{31}$

\section{Data collection process}

The data were collected from the absolute values provided or inferred based on information reported in the included studies. A Quality Assessment of Diagnostic Accuracy Studies (QUADAS)-based checklist was used and the collected data were placed into $2 \times 2$ tables. $^{32,33}$ These tables separated the true positives (TP), false positives (FP), true negatives (TN), and false negatives (FN). Only studies that provided all the information necessary to complete the table for at least one analysis were included in the meta-analysis. This process was performed by three independent reviewers and revised by all authors. Disagreements were resolved by consensus among the authors.

\section{Data items}

Population characteristics (number of patients with suspect- 
ed malignant biliary strictures included in the analysis, clinical indications for the procedure), study design, gold-standard method used, EUS-FNA, and ERCP-based tissue sampling results were obtained from the included studies. The term "same-session tissue sampling" was defined as EUS and ERCP sampling procedures performed on the same day or within a maximum of 14 days without knowledge of prior cytopathologic results. Patients with malignant lesions on both endoscopic sampling and gold standard methods were considered TP, whereas patients with benign lesions on both endoscopic sampling and gold-standard methods were considered TN. Patients who had malignant disease (based on the gold standard evaluation) that was classified as benign by endoscopic methods were considered FN, whereas patients who had benign lesions (based on the gold standard evaluation) that was classified as malignant by endoscopic procedures were considered FP.

\section{Risk of bias}

To evaluate the risk of bias and applicability of primary diagnostic accuracy, the QUADAS-2 tool was used. This tool consists of four key domains, each of which are assessed in terms of risk of bias: patient selection, index test, reference standard, and flow and timing. The first three domains are also assessed in terms of applicability.

\section{Summary measures and synthesis of results}

For the quantitative analysis, sensitivity, specificity, $+\mathrm{LR}$ and -LR values are presented in Forest plots. Additionally, summary receiver operating characteristic (sROC) curves and estimations of the AUCs were performed. All variables were subjected to intention-to-treat (ITT) analysis, where atypical and suspicious cases were considered malignant, and acquisition failure and inconclusive cases were considered benign. I-square was used to evaluate heterogeneity. Due to the heterogeneity among the studies, the Dersimonian Laird random effects model was used in the analysis. The sROC curves were created using the Moses-Littenberg linear model. Data entered (including TP, FP, TN, and FN) were converted to percentage values and graphs by the software Meta-DiSc version 1.4. Ad-
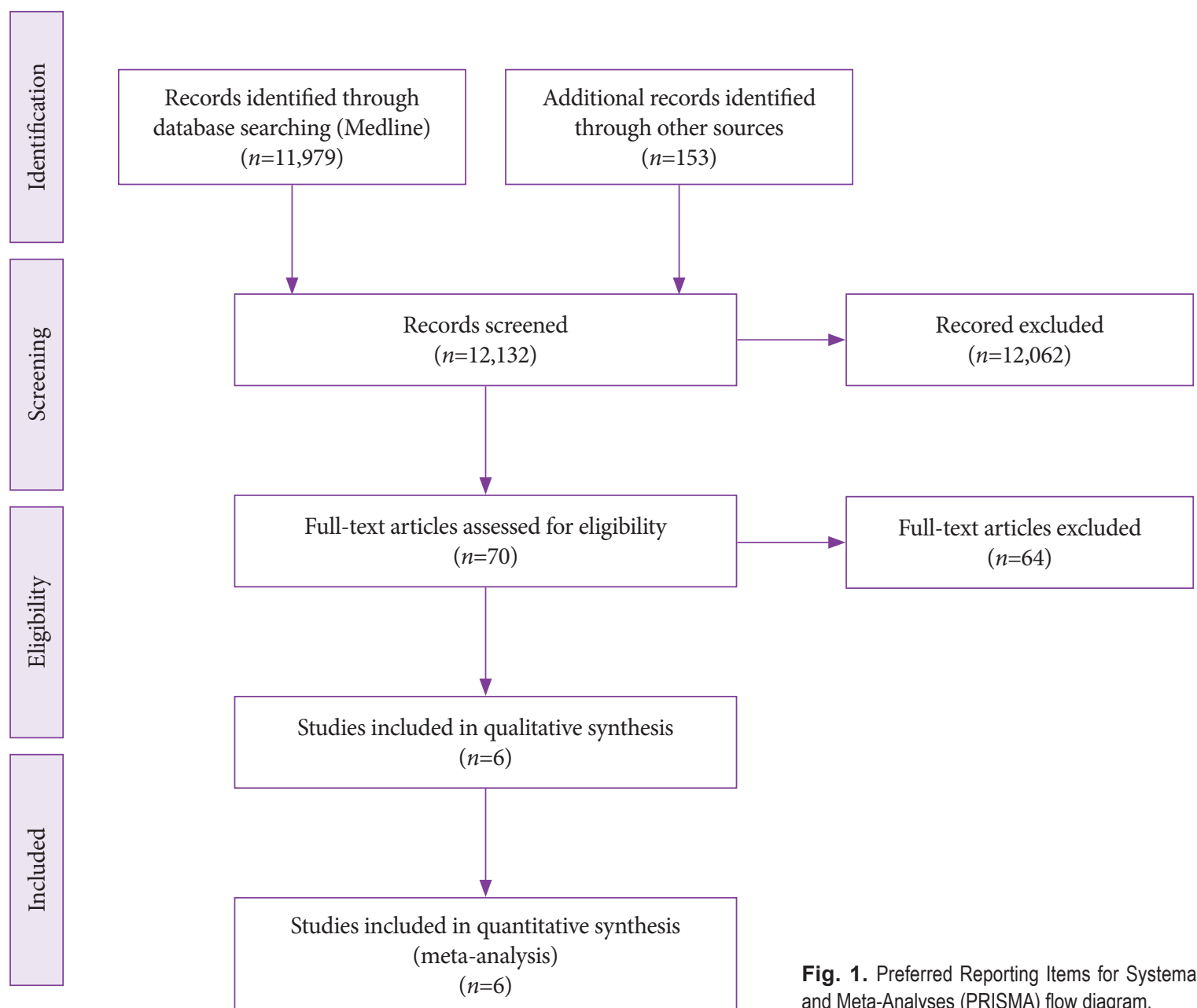

$$
(n=12,062)
$$

Full-text articles excluded $(n=64)$

Fig. 1. Preferred Reporting Items for Systematic Reviews and Meta-Analyses (PRISMA) flow diagram. 
Table 1. Characteristics of Included Studies

\begin{tabular}{|c|c|c|c|c|c|c|}
\hline Study & $\begin{array}{c}\text { Patients } \\
\text { (n) }\end{array}$ & $\begin{array}{l}\text { Age } \\
(\mathrm{yr})\end{array}$ & Lesion size & Intervention & Gold standard & Final diagnosis \\
\hline $\begin{array}{l}\text { Design: } \\
\text { Retrospective }\end{array}$ & $\begin{array}{l}263 \\
\text { M: } 167 \\
\text { F: } 96\end{array}$ & $64.6 \pm 10.5$ & $26.9 \pm 11.6 \mathrm{~mm}$ & $\begin{array}{l}\text { EUS-FNA ( } 22 \mathrm{G}, 25 \mathrm{H}, \\
20 \mathrm{G} \text { and } 19 \mathrm{G}): 2.7 \\
( \pm 1.2) \text { passes } \\
\text { ERCP: } 3 \text { (1-7) in- } \\
\text { traductal biopsy in } \\
246 / 257 \text { cases and } \\
\text { cytology (via endo- } \\
\text { scopic nasobiliary } \\
\text { drainage or brushing } \\
\text { in all cases) }\end{array}$ & $\begin{array}{l}\text { 1) Surgical pathology; } 2 \text { ) } \\
\text { pathologic diagnosis } \\
\text { made by any tissue } \\
\text { acquisition method; } 3 \text { ) } \\
\text { follow-up (>6 mo) }\end{array}$ & $\begin{array}{l}\text { Malignant: } 239 \\
\text { - Pancreatic mass: } 163 \\
\text { - CCA: } 53 \\
\text { - Gallbladder cancer: } 14 \\
\text { - Other: } 9 \\
\text { Benign: } 24 \\
\text { - Autoimmune pancreatitis: } \\
\text { 12 } \\
\text { - Chronic pancreatitis: } 5 \\
\text { - Other: } 7\end{array}$ \\
\hline $\begin{array}{l}\text { Moura et al. } \\
(2018)^{2} \\
\text { Design: } \\
\text { Prospective }\end{array}$ & $\begin{array}{l}50 \\
\text { M: } 24 \\
\text { F: } 26\end{array}$ & $\begin{array}{c}63.08 \\
(41-86)\end{array}$ & $\begin{array}{c}3.48 \pm 1.72 \\
\mathrm{~cm}\end{array}$ & $\begin{array}{l}\text { EUS-FNA ( } 22 \mathrm{G}): 4 \\
\text { passes } \\
\text { ERCP: } 3 \text { intraductal } \\
\text { biopsies and } 2 \text { brush } \\
\text { cytology }\end{array}$ & $\begin{array}{l}\text { 1) Surgical pathology; } 2) \\
\text { clinical follow-up (>6 } \\
\text { mo) }\end{array}$ & $\begin{array}{l}\text { Malignant: } 48 \\
\text { - Adenocarcinoma: } 36 \\
\text { - IPMN: } 4 \\
\text { - Metastases: } 3 \\
\text { - Neuroendocrine tumor: } 2 \\
\text { - Adenosquamous: } 1 \\
\text { - Other: } 2 \\
\text { Benign: } 2 \\
\text { - Fibrosis: } 2\end{array}$ \\
\hline $\begin{array}{l}\text { Weilert et al. } \\
(2014)^{3} \\
\text { Design: } \\
\text { Prospective }\end{array}$ & 51 & $\begin{array}{c}67 \\
(42-88)\end{array}$ & N/A & $\begin{array}{l}\text { EUS-FNA ( } 22 \text { G or } 25 \\
\text { G) - with ROSE } \\
\text { ERCP: } 2 \text { to } 3 \text { intra- } \\
\text { ductal biopsies and } \\
\text { brush cytology }\end{array}$ & $\begin{array}{l}\text { 1) Surgical findings/ } \\
\text { pathology; 2) EUS or } \\
\text { ERCP sampling with } \\
\text { definite evidence } \\
\text { for malignancy; and 3) } \\
\text { clinical follow-up } \\
\text { (>6 mo) }\end{array}$ & $\begin{array}{l}\text { Malignant: } 48 \\
\text { - Pancreatic cancer: } 34 \\
\text { - CCA: } 13 \\
\text { - Gallbladder cancer: } 1 \\
\text { Benign: } 3 \\
\text { - Autoimmune pancreatitis: } \\
1 \\
\text { - Chronic pancreatitis: } 1 \\
\text { - Autoimmune cholangiop- } \\
\text { athy: } 1\end{array}$ \\
\hline $\begin{array}{l}\text { Design: } \\
\text { Prospective }\end{array}$ & $\begin{array}{l}46 \\
\text { M: } 21 \\
\text { F: } 25\end{array}$ & $\begin{array}{c}56 \\
(40-87)\end{array}$ & N/A & $\begin{array}{l}\text { EUS-FNA ( } 22 \mathrm{G}) \text { : at } \\
\text { least } 3 \text { passes-with } \\
\text { ROSE (by the endos- } \\
\text { copist) } \\
\text { ERCP brush cytology }\end{array}$ & $\begin{array}{l}\text { 1) Surgical pathology; 2) } \\
\text { EUS or ERCP sampling } \\
\text { with evidence for ma- } \\
\text { lignancy; and 3) clinical } \\
\text { follow-up } \\
\text { (>6 mo for malignance } \\
\text { and } 24 \text { mo for benign) }\end{array}$ & $\begin{array}{l}\text { Malignant: } 37 \\
\text { - Pancreatic cancer: } 26 \\
\text { - Biliary: } 11 \\
\text { - Common bile duct: } 8 \\
\text { - Hilar tumors: } 3 \\
\text { Benign: } 9 \\
\text { - Chronic pancreatitis: } 8 \\
\text { - Fibrosis: } 2\end{array}$ \\
\hline $\begin{array}{l}\text { Oppong et al. } \\
(2010)^{6} \\
\text { Design: } \\
\text { Retrospective }\end{array}$ & 37 & $\begin{array}{c}62.4 \\
(26-87)\end{array}$ & N/A & $\begin{array}{l}\text { EUS-FNA ( } 22 \text { G and } \\
25 \text { G): } 2.7(1-6) \text { pass- } \\
\text { es } \\
\text { ERCP brush cytology: } \\
\text { at least } 3 \text { brushings }\end{array}$ & $\begin{array}{l}\text { 1) Surgical histology or } \\
\text { other biopsy methods; } \\
\text { 2) any positive cytology } \\
\text { result combined with } \\
\text { clinical follow-up } \\
\text { with evidence of ma- } \\
\text { lignancy; 3) follow-up } \\
\text { until death or for at } \\
\text { least two years if there } \\
\text { was no evidence of } \\
\text { malignancy }\end{array}$ & $\begin{array}{l}\text { Malignant: } 32 \\
\text { - Pancreatic tumor: } 29 \\
\text { - Neuroendocrine tumor: } 2 \\
\text { - CCA: } 1 \\
\text { Benign: } 5 \\
\text { - Chronic pancreatitis: } 2 \\
\text { - Primary sclerosing chol- } \\
\text { angitis: } 1 \\
\text { - Serous cyst adenoma: } 1 \\
\text { - GIST: } 1\end{array}$ \\
\hline
\end{tabular}


Table 1. Continued.

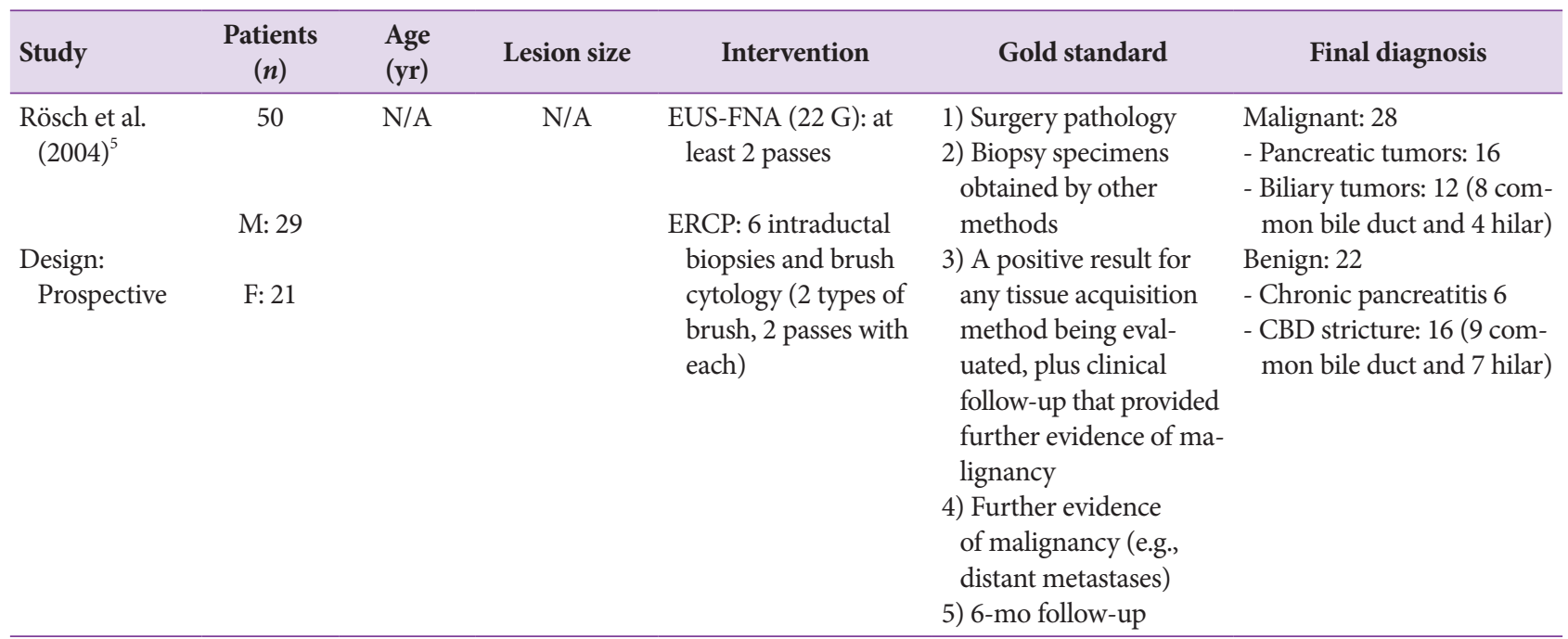

CBD, common biliary duct; CCA, cholangiocarcinoma; ERCP, endoscopic retrograde cholangiopancreatography; EUS-FNA, endoscopic ultrasound-guided fine needle aspiration; GIST, gastrointestinal; IPMN, intraductal papillary mucinous neoplasms; N/A, not available; ROSE, rapid on site evaluation.

ditionally, the adverse events for each study were reported.

\section{RESULTS}

\section{Study selection}

In the initial search, 12,132 studies were screened and assessed for eligibility based on their titles and abstracts. Of these, 12,062 were excluded because they were not related to our objective. Of the remaining 70 studies, 64 did not meet inclusion criteria and were excluded. Therefore, a total of six studies ${ }^{2,3,5,6,9,34}$ were included for qualitative analysis, including four ${ }^{2,3,534}$ prospective and two ${ }^{6,9}$ retrospective studies. These studies also provided adequate information for inclusion in the quantitative analysis. This process is summarized in Fig. 1.

\section{Study characteristics}

The important characteristics of the selected studies are summarized in Table 1. These data were extracted through careful reading of included papers. The design, patient characteristics, lesion characteristics, interventions, and gold standard methods of diagnosis were similar for among these studies. The inclusion criteria were jaundice or elevated liver functions tests and suspected malignant biliary stricture identified on imaging. The main objective of all included studies was to evaluate same-session EUS/ERCP-based tissue sampling in the diagnosis of malignant biliary strictures.

\section{Risk of bias within and across studies}

Using QUADAS-2, we found that the risk of bias within studies was low. When assessing risk of bias during patient selection, we found that all studies demonstrated a low risk of bias. Regarding interpretation of the index test and gold-standard methods, all studies also showed a low risk of bias. Additionally, patient flow did not introduce bias in any included study (Table 2).

\section{Results of individual studies}

Pretest probability, sensitivity, specificity, positive predictive value, negative predictive values, and accuracy were assessed in all studies. The prevalence of malignant disease was $>50 \%$ in all included studies. During our evaluation, we found that the specificity of both tests was satisfactory in all studies with values ranging from $88.9 \%$ to $100 \%$. EUS-FNA was more accurate than ERCP-based tissue sampling in all studies except for the study by Rösch et al., in which both methods demonstrated similar results. ${ }^{5}$

\section{Synthesis of results}

A total of six studies were included in the ITT analysis, for a total of 497 patients. Of these, 432 (86.92\%) patients had lesions that were considered malignant (268 pancreatic masses, 90 CCAs, 15 cases of gallbladder cancer, 4 neuroendocrine tumors, 3 metastases, and 52 other lesions) and 65 (13.08\%) patients had lesions that were considered benign (22 cases of chronic pancreatitis, 13 cases of autoimmune pancreatitis, and 30 other lesions). The number of studies included in each analysis varied according to the available data in each study.

First, the association between EUS-FNA and ERCP-based tissue sampling was analyzed. This analysis included 5 studies, 
and the results were: pooled sensitivity of $86 \%(0.83-0.90)$, $\mathrm{I}^{2}=78.5 \%$; pooled specificity of $98 \%(0.91-1.00), \mathrm{I}^{2}=0 \%$; pooled + LR of $12.50(4.23-36.88) \mathrm{I}^{2}=0 \%$; and pooled $-\mathrm{LR}$ of 0.17 (0.11-0.28), $\mathrm{I}^{2}=54 \%$ (Fig. 2). Additionally, the AUC was 0.9656 (Fig. 3).

When comparing EUS-FNA to ERCP-based tissue sampling, all six studies were included in the analysis. EUS-FNA showed better results than ERCP. For EUS-FNA, the pooled sensitivity, specificity, +LR, $-\mathrm{LR}$ and AUC were: $76 \%(0.72-$ $0.80), I^{2}=87.3 \% ; 100 \%$ (0.94-1.00), $I^{2}=0 \% ; 10.95$ (3.73-32.13), $\mathrm{I}^{2}=0 \%$; 0.27 (0.18-0.43), $\mathrm{I}^{2}=78.2 \%$; and 0.9458, respectively (Fig. 4). For ERCP, the pooled sensitivity, specificity, $+\mathrm{LR},-\mathrm{LR}$ and AUC were: $58 \%$ (0.53-0.62), $\mathrm{I}^{2}=65.9 ; 98 \%(0.92-1.00), \mathrm{I}^{2}=0 \%$; $7.51(2.75-20.51), \mathrm{I}^{2}=0 \% ; 0.47(0.40-0.56), \mathrm{I}^{2}=21.9 \%$; and 0.7819 , respectively (Fig. 5).

Secondly, a comparison between methods was performed for pancreatic and biliary etiologies individually. In this anal- ysis four studies were included. In the pancreatic lesions analysis, Moura et al. ${ }^{2}$ was excluded since this study did not report any benign cases of pancreatic lesions, preventing the calculations of specificity and $+\mathrm{LR}$. In the pancreatic analysis, EUSFNA was superior to ERCP-based tissue sampling. For EUSFNA, the pooled sensitivity, specificity, $+\mathrm{LR},-\mathrm{LR}$ and AUC were: $75 \%(0.69-0.81), \mathrm{I}^{2}=80.7 \% ; 100 \%(0.87-100), \mathrm{I}^{2}=0 \% ; 10.59$ (2.29-48.91), $\mathrm{I}^{2}=0 \%$; 0.27 (0.16-0.47), $\mathrm{I}^{2}=56.5 \%$; and 0.9422, respectively (Fig. 6). For ERCP-based tissue sampling, the pooled sensitivity, specificity, $+\mathrm{LR},-\mathrm{LR}$ and AUC were: $47 \%$ (0.40-0.53), $\mathrm{I}^{2}=78.1 \%$; $100 \%$ (0.87-1.00), $\mathrm{I}^{2}=0 \%$; 4.90 (1.0223.59), $\mathrm{I}^{2}=0 \%$; $0.66(0.43-1.01), \mathrm{I}^{2}=82.3 \%$; and 0.7930 ; respectively (Fig. 7). In the biliary lesion analysis, both methods had similar results. For EUS-FNA, the sensitivity, specificity, $+\mathrm{LR}$, -LR, and accuracy were: 71\% (0.62-0.79), $\mathrm{I}^{2}=76.4 \% ; 100 \%$ (0.86-1.00), $\mathrm{I}^{2}=0 \%$; 10.35 (1.56-21.28), $\mathrm{I}^{2}=0 \%$; 0.38 (0.19-0.75), $\mathrm{I}^{2}=79.6 \%$; and 0.8832 (Fig. 8). For ERCP-based tissue sampling,

Table 2. Quality Assessment of Diagnostic Accuracy Studies-2. Risk of Bias Across the Included Studies

\begin{tabular}{|c|c|c|c|c|c|c|c|}
\hline \multirow[b]{2}{*}{ Study } & \multicolumn{4}{|c|}{ Risk of bias } & \multicolumn{3}{|c|}{ Applicability concerns } \\
\hline & $\begin{array}{c}\text { Patient } \\
\text { selection }\end{array}$ & Index test & $\begin{array}{l}\text { Reference } \\
\text { standard }\end{array}$ & $\begin{array}{c}\text { Flow and } \\
\text { timing }\end{array}$ & $\begin{array}{c}\text { Patient } \\
\text { selection }\end{array}$ & Index test & $\begin{array}{l}\text { Reference } \\
\text { standard }\end{array}$ \\
\hline Jo et al. $(2019)^{9}$ & (:) & (:) & (:) & (:) & (:) & (;) & (:) \\
\hline Moura et al. $(2018)^{2}$ & (:) & ;) & (:) & (;) & (:) & (:) & (:) \\
\hline Weilert et al. (2014) & ;) & ;) & ;) & ;) & ;) & ;) & ;) \\
\hline Novis et al. $(2010)^{34}$ & ;) & ;) & ;:) & (;) & ;) & (;) & (;) \\
\hline Oppong et al. $(2010)^{6}$ & ;) & ;) & ;:) & ;) & ;) & ;) & ;) \\
\hline Rösch et al. $(2004)^{5}$ & (;) & (:) & ;) & ;) & (;) & (;) & (;) \\
\hline
\end{tabular}

() Low risk $\quad$ - High risk
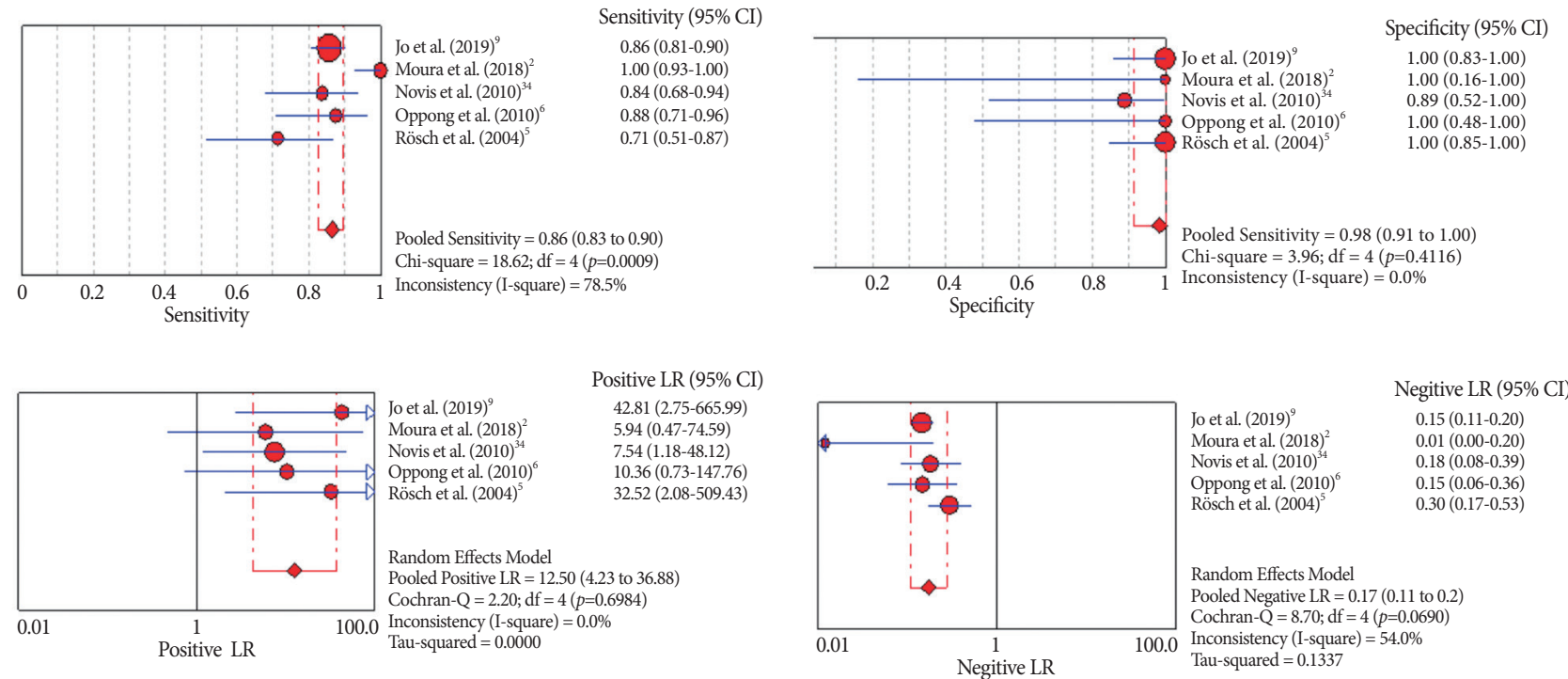

Fig. 2. Forest plots of the sensitivity, specificity, positive likelihood ratio (LR) and negative LR of the association of endoscopic ultrasound-guided fine needle aspiration and endoscopic retrograde cholangiopancreatography-based tissue sampling in the diagnosis of suspected malignant biliary strictures. $\mathrm{Cl}$, confidence interval. 
the sensitivity, specificity, $+\mathrm{LR},-\mathrm{LR}$, and accuracy were: $74 \%$ (0.65-0.82), $\mathrm{I}^{2}=0 \% ; 100 \%$ (0.86-1.00), $\mathrm{I}^{2}=0 \% ; 7.03$ (1.93-25.65), $\mathrm{I}^{2}=0 \% ; 0.29$ (0.21-0.41); 0.8097 (Fig. 9). Table 3 summarizes all the meta-analysis results from EUS-FNA and ERCP-based tissue sampling.

Third, both ERCP-based tissue sampling methods (i.e., BC and FB) were compared individually. In the individual analysis, each method produced inferior results compared to both methods combined. For BC, four studies ${ }^{2,5,6,34}$ were analyzed; for $\mathrm{FB}$, two studies ${ }^{2,5}$ were analyzed. The $\mathrm{BC}$ analysis showed a

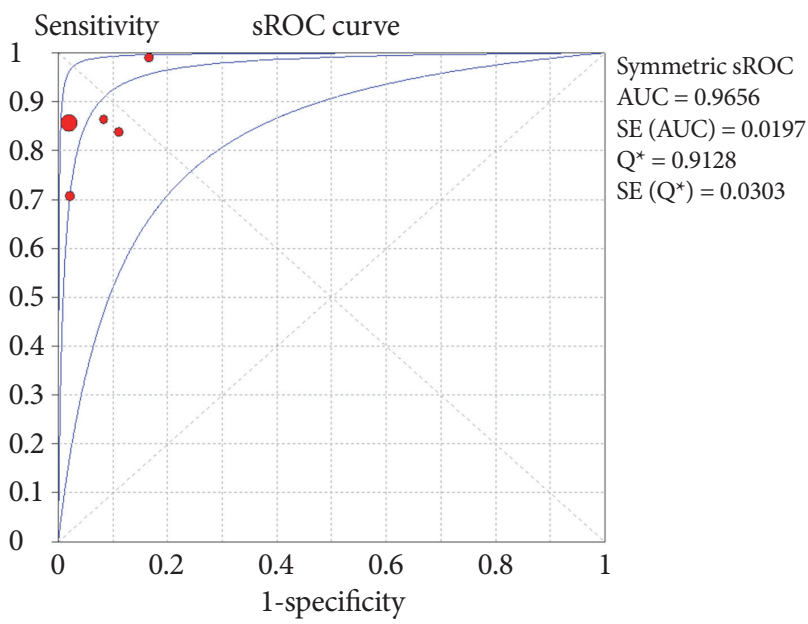

Fig. 3. Summary receiver operating characteristic (sROC) curve of the association of endoscopic ultrasound-guided fine needle aspiration and endoscopic retrograde cholangiopancreatography-based tissue sampling in the diagnosis of suspected malignant biliary strictures. AUC, area under the curve; SE, standard error.
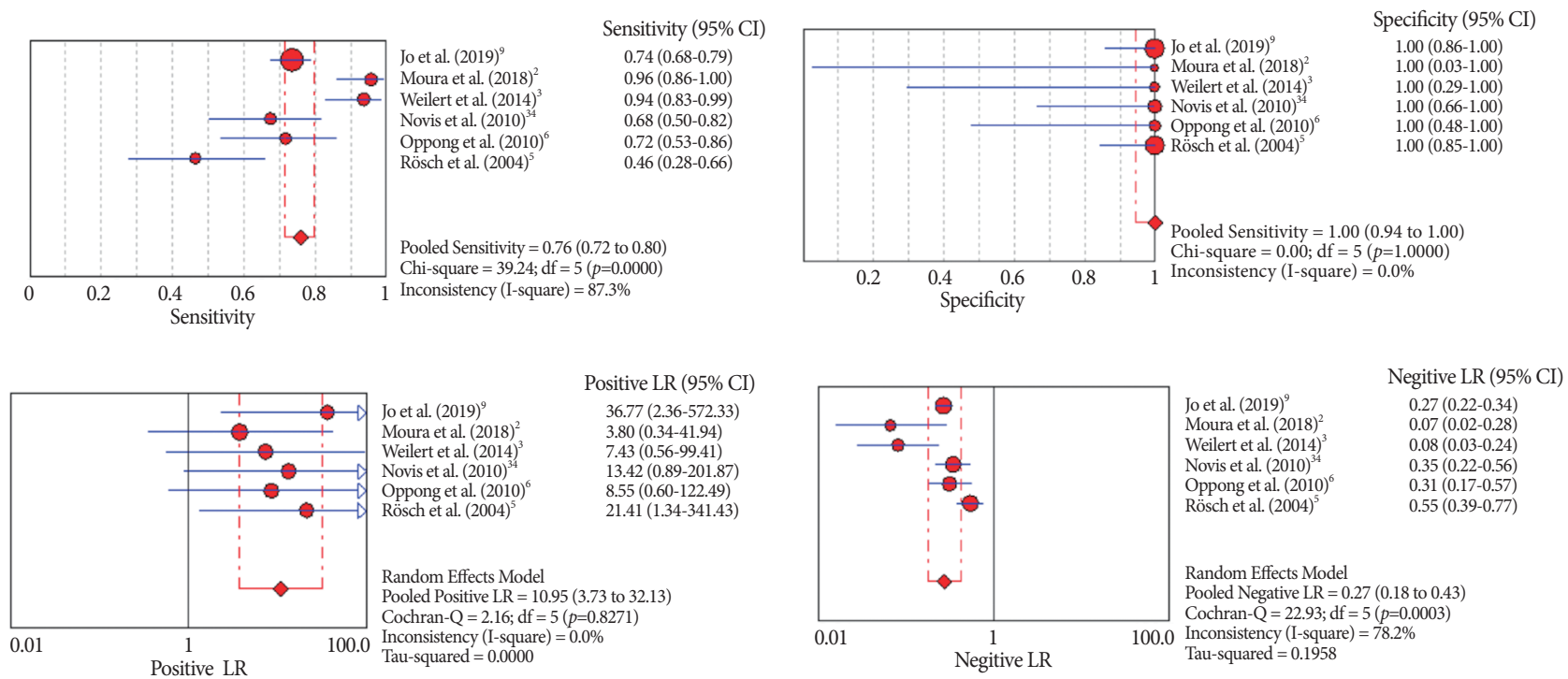

Fig. 4. Forest plots of the sensitivity, specificity, positive likelihood ratio (LR) and negative LR of endoscopic ultrasound-guided fine needle aspiration in the diagnosis of suspected malignant biliary strictures. $\mathrm{Cl}$, confidence interval. sensitivity and specificity of $54 \%(0.46-0.63), \mathrm{I}^{2}=0 \%$; and $97 \%$ (0.86-1.00), $\mathrm{I}^{2}=0 \%$, respectively. The FB analysis showed a sensitivity and specificity of $43 \%(0.32-0.55), \mathrm{I}^{2}=7.5 \%$; and $100 \%$ $(0.86-1.00), I^{2}=0 \%$, respectively.

The adverse events related to the combination of the procedures in each study are described in Table 4.

\section{DISCUSSION}

Biliary strictures can emerge from the epithelium, such as in primary sclerosing cholangitis or CCA, or due to extraluminal compression from masses or regional inflammatory processes.

When a mass is clearly defined, diagnosis is often easily obtained via EUS-FNA, with a sensitivity and accuracy of up to 95\%. Conversely, a stricture after liver transplantation or following iatrogenic bile duct injury, can easily be diagnosed as benign. However, when a clear mass is absent, and the clinical history is poor or unclear, differentiation between benign and malignant biliary strictures can be challenging. In such cases, confirmation through histological diagnosis is crucial to, firstly, avoid operations of a benign disease with potentially undue morbidity and mortality, or secondly, leave an undiagnosed malignancy unchecked. ${ }^{1,2,35,36}$

Seeking to define the best approach for tissue diagnosis of biliary strictures, we conducted this systematic review and meta-analysis to report performance data on same-session EUS-FNA and ERCP-based tissue sampling. We included all studies $^{2,3,5,6,9,34}$ that performed ERCP-based tissue sampling and EUS-FNA in the diagnosis of malignant biliary strictures 


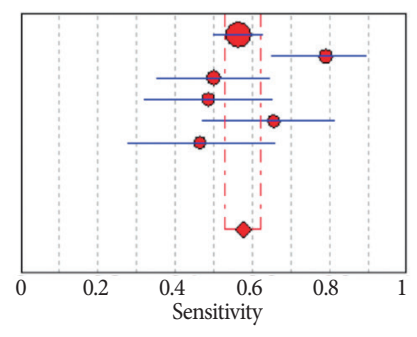

Jo et al. $(2019)^{9}$ Moura et al. (2018) Weilert et al. (2014) Novis et al. (2010) Oppong et al. (2010) Rösch et al. (2004)

Pooled Sensitivity $=0.58$ ( 0.53 to 0.62$)$ Chi-square $=14.64 ; \mathrm{df}=5(p=0.0119)$ Inconsistency (I-square) $=65.9 \%$

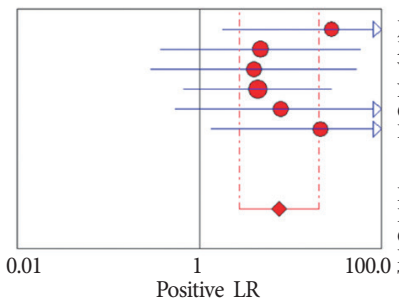
Jo et al. (2019) Weilert et al. (2014) Novis et al. (2010) Oppong et al. (2010) Rösch et al. (2004)

Random Effects Mode Pooled Positive LR = 7.51 (2.75 to 20.51) Cochran $-\mathrm{Q}=2.48 ; \mathrm{df}=5(p=0.7789)$

Positive LR Inconsistency (I-square) $=0.0 \%$

Positive LR (95\% CI) 28.23 (1.81-439.91) $4.71(0.37-59.45)$ $4.00(0.29-54.28)$ $4.38(0.67-28.62)$ $7.87(0.54-112.39)$ $21.41(1.34-341.43)$

Fig. 5. Forest plots of the sensitivity, specificity, positive likelihood ratio (LR) and negative LR of endoscopic retrograde cholangiopancreatography-based tissue sampling in the diagnosis of suspected malignant biliary strictures. $\mathrm{Cl}$, confidence interval.

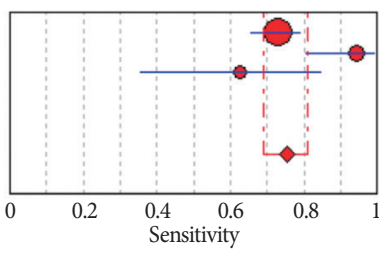

o et al. $(2019)^{9}$ Weilert et al. (2014) Rösch et al. (2004)

Pooled Sensitivity $=0.75$ (0.69 to 0.81 ) Pooled Sensitivity $=0.75$ (0.69 to 0.81$)$ Chi-square $=10.38 ; \mathrm{df}=2(p=0.0056)$
Inconsistency $(\mathrm{I}$-square $)=80.7 \%$

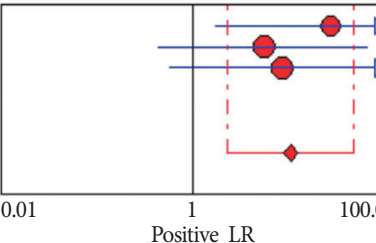

$\begin{array}{ll}\text { Jo et al. }(2019)^{9} & 27.61(1.79-426.10) \\ \text { Weilert et al. }(2014)^{3} & 5.57(0.44-70.08) \\ \text { Rösch et al. }(2004)^{5} & 8.65(0.58-128.29) \\ & \\ \text { Random Effects Model } & \\ \text { Pooled Positive LR }=10.95(0.29 \text { to } 48.91) \\ \text { Cochran- } \mathrm{Q}=0.89 ; \mathrm{df}=2(p=0.6421) \\ \text { Inconsistency }(\mathrm{I}-\mathrm{square})=0.0 \%\end{array}$
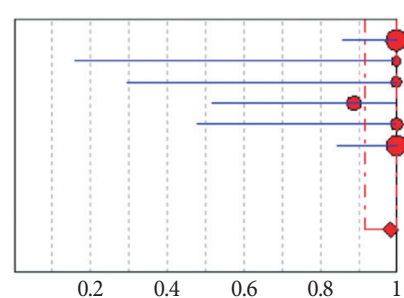

Jo et al. (2019) Moura et al. (2018) Weilert et al. (2014) Oppong et al. (2010) Oppong et al. (2010)

Specificity $(95 \%$ CI $)$

$1.00(0.86-1.00)$

$1.00(0.16-1.00)$

$1.00(0.29-1.00)$
$0.89(0.52-1.00)$

$1.00(0.48-1.00)$

$1.00(0.85-1.00)$

Pooled Sensitivity $=0.98(0.92$ to 1.00$)$

Chi-square $=4.05 ; \mathrm{df}=5(p=0.5416)$

Inconsistency (I-square) $=0.0 \%$

$\begin{array}{ccr}0.2 & 0.4 & 0.6 \\ & & \text { Specificity }\end{array}$

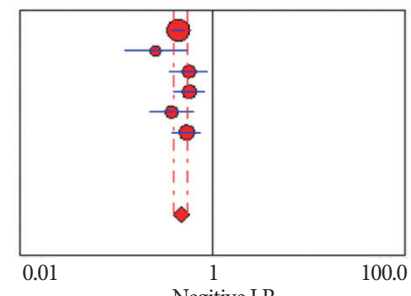

Negitive LR (95\% CI)

$0.26(0.12-0.54)$

$0.57(0.36-0.91)$

$0.38(0.22-0.64)$

$0.55(0.39-0.77)$

Random Effects Model

Dooled Negative LR $=0.47$ ( 0.40 to 0.56 )

$\mathrm{Q}=6.41 ; \mathrm{df}=5(p=0.2687)$

Tau-squared $=0.0095$ oet al. $(2019)^{9} \quad 0.44(0.38-0.52)$
Specificity $(95 \% \mathrm{CI})$

$1.00(0.81-1.00)$

$1.00(0.54-1.00)$
Fig. 6. Forest plots of the sensitivity, specificity, positive likelihood ratio (LR) and negative LR of endoscopic ultrasound-guided fine needle aspiration in the diagnosis of pancreatic lesion causing biliary strictures. $\mathrm{Cl}$, confidence interval.

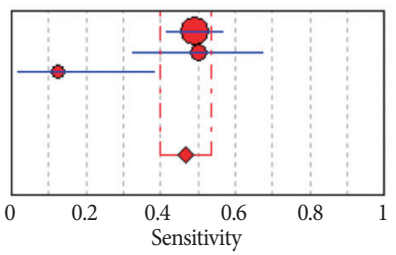

Jo et al. (2019) Weilert et al. (2014)
Rösch et al. (2004)

Pooled Sensitivity $=0.47$ ( 0.40 to 0.53 ) Chi-square $=9.15 ; \mathrm{df}=2(p=0.0103)$

$$
\begin{gathered}
\text { Sensitivity (95\% CI) } \\
0.49(0.41-0.57) \\
0.50(0.32-0.68) \\
0.13(0.02-0.38)
\end{gathered}
$$

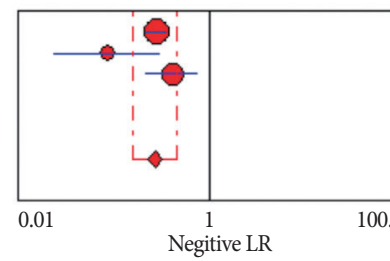

Jo Weilert et al. (2014) Rösch et al. (2004)

Negitive LR $(95 \%$ CI) $0.28(0.22-0.36)$ $0.09(0.02-0.31)$ $0.41(0.22-0.78)$

Random Effects Mode Pooled Negative LR $=0.27$ (0.16 to 0.47 ) Cochran- $\mathrm{Q}=4.59 ; \mathrm{df}=2(p=0.1006)$ Inconsistency (I-square) $=56.5 \%$ Tau-squared $=0.1287$ 

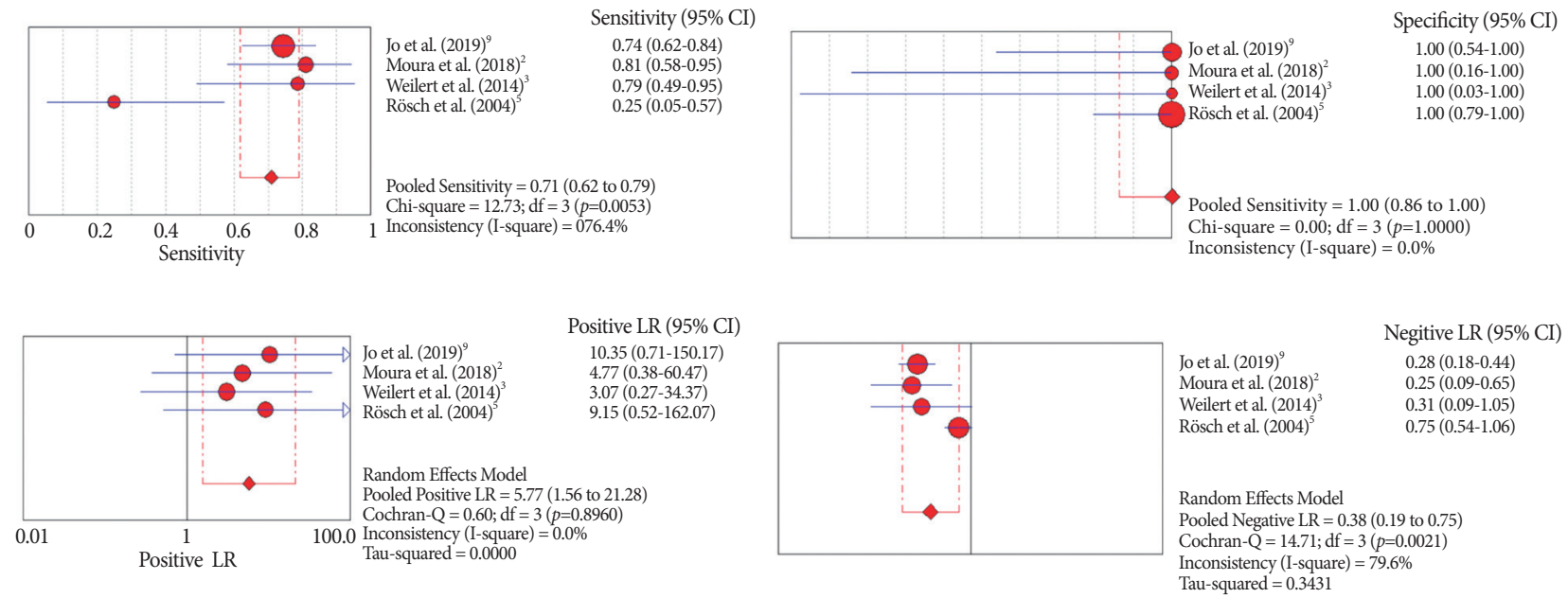

Fig. 8. Forest plots of the sensitivity, specificity, positive likelihood ratio $(L R)$ and negative LR of endoscopic ultrasound-guided fine needle aspiration in the diagnosis of biliary lesions. $\mathrm{Cl}$, confidence interval.
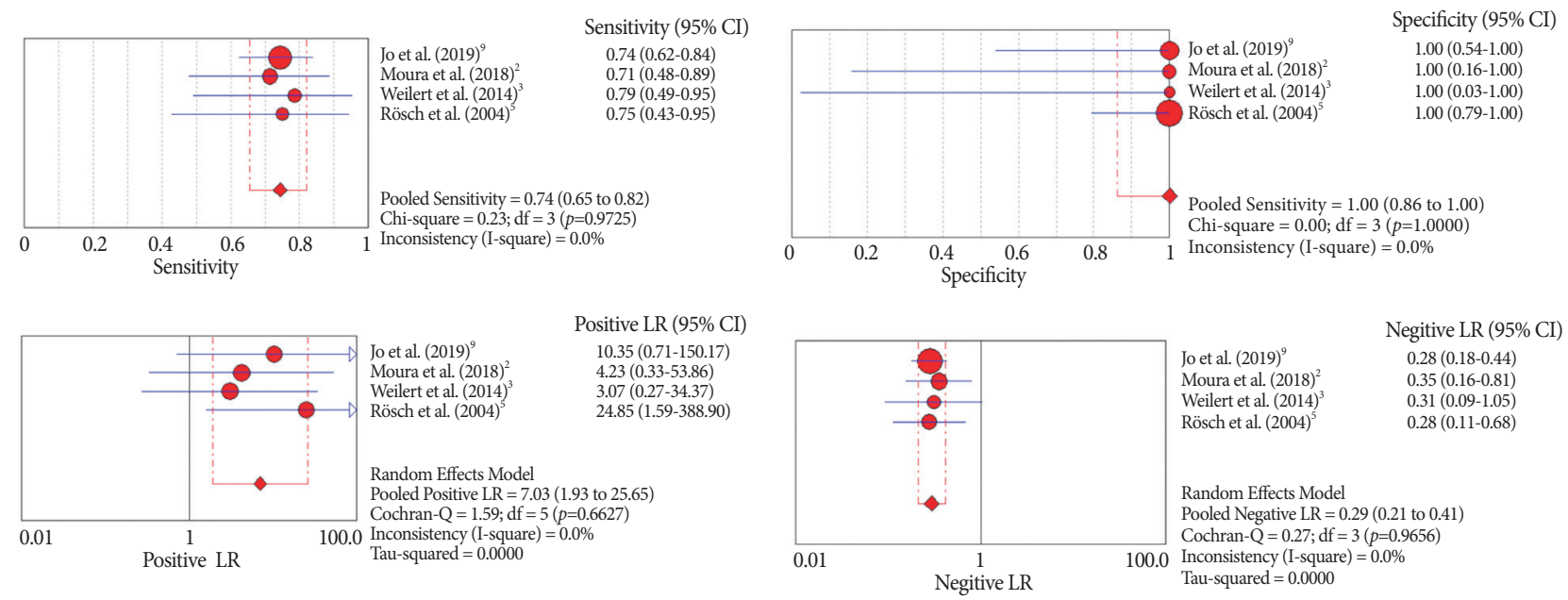

Fig. 9. Forest plots of the sensitivity, specificity, positive likelihood ratio (LR) and negative LR of endoscopic retrograde cholangiopancreatography-based tissue sampling in the diagnosis of biliary lesions. $\mathrm{Cl}$, confidence interval.

Table 3. Summary of the Meta-Analysis Results

\begin{tabular}{lccccc}
\hline Method(s) & Sensitivity (\%) & Specificity (\%) & $\begin{array}{c}\text { Positive likelihood } \\
\text { ratio }\end{array}$ & $\begin{array}{c}\text { Negative likelihood } \\
\text { ratio }\end{array}$ & $\begin{array}{c}\text { Area under the } \\
\text { curve- sROC }\end{array}$ \\
\hline EUS + ERCP & $86(81-90)$ & $98(91-100)$ & $12.50(4.23-36.88)$ & $0.17(0.11-0.28)$ & 0.9656 \\
EUS & $76(72-80)$ & $100(94-100)$ & $10.95(3.73-32.13)$ & $0.27(0.18-0.43)$ & 0.9458 \\
ERCP & $58(53-62)$ & $98(92-100)$ & $7.51(2.75-20.51)$ & $0.47(0.40-0.56)$ & 0.7819 \\
EUS-FNA in pancreatic lesions & $75(65-81)$ & $100(87-100)$ & $10.59(2.29-48.91)$ & $0.27(0.16-0.47)$ & 0.9422 \\
ERCP in pancreatic lesions & $47(40-53)$ & $100(87-100)$ & $4.90(1.02-23.59)$ & $0.66(0.43-1.01)$ & 0.7930 \\
EUS-FNA in biliary lesions & $71(62-79)$ & $100(86-100)$ & $5.77(1.56-21.28)$ & $0.38(0.19-0.75)$ & 0.8832 \\
ERCP in biliary lesions & $74(65-82)$ & $100(86-100)$ & $7.03(1.93-25.65)$ & $0.29(0.21-0.41)$ & 0.8097 \\
\hline
\end{tabular}

ERCP, endoscopic retrograde cholangiopancreatography; EUS-FNA, endoscopic ultrasound-guided fine needle aspiration; sROC, summary receiver operating characteristic. 
Table 4. Adverse Events Related to Combined Procedures of Each Included Study

\begin{tabular}{|c|c|c|c|}
\hline Study & Patients, $n$ & Adverse events, $n$ (\%) & Adverse events \\
\hline Jo et al. $(2019)^{9}$ & 263 & $24(9.12)$ & $\begin{array}{l}-8 \text { bleedings } \\
-2 \text { cholangitis } \\
-14 \text { pancreatitis }\end{array}$ \\
\hline Moura et al. $(2018)^{2}$ & 50 & $3(6)$ & $\begin{array}{l}-2 \text { mild pancreatitis } \\
-1 \text { post sphincterotomy bleeding without hemodynamic reper- } \\
\text { cussion, treated endoscopically }\end{array}$ \\
\hline Weilert et al. $(2014)^{3}$ & 51 & 0 & No adverse events \\
\hline Novis et al. $(2010)^{34}$ & 46 & $5(10.86)$ & $\begin{array}{l}-2 \text { cholangitis treated endoscopically } \\
-1 \text { mild pancreatitis } \\
-1 \text { biliary peritonitis. Surgical intervention was required. Patient } \\
\text { died after surgery } \\
\text { - } 1 \text { mild bleeding. No intervention was required }\end{array}$ \\
\hline Oppong et al. $(2010)^{6}$ & 37 & $2(9.1)$ & $\begin{array}{l}-1 \text { mild pancreatitis } \\
-1 \text { inadequate biliary drainage after procedures. Stent exchange } \\
\text { was required }\end{array}$ \\
\hline Rösch et al. $(2004)^{5}$ & 50 & 0 & No adverse events \\
\hline
\end{tabular}

in the same-session or within a few days in some cases. In four studies, ${ }^{2,3,5}$ during ERCP, both BC and FB were performed, and in two studies, ${ }^{6,34}$ just $\mathrm{BC}$ was performed.

Most histopathology reports use five different categories including inadequate, benign, atypical, suspect or malignant. ${ }^{2,37}$ Diagnostic studies disagree on whether to consider cases with suspicious results as malignant or benign, and this fact is related to the heterogeneity of diagnostic yields reported in the literature. To avoid heterogeneity in our findings, in our analysis, we included data in an ITT analysis and considered atypical and cases with suspicious results as malignant, and inconclusive cases as benign.

Our first goal was to analyze the diagnostic yield of same-session EUS-FNA and ERCP-based tissue sampling. The pooled sensitivity was higher when the methods were combined compared to either method alone. With both methods combined we found a pooled sensitivity of $86 \%$, with a $+\mathrm{LR}$ of 12.50 , meaning that a malignant result can be trusted. However, even with both methods combined, the -LR was 0.17 , meaning a negative result for a suspected malignant lesion. Therefore, these results should be interpreted with caution, and cannot exclude malignancy. Theoretically, the combined use of these techniques could increase the number of complications, since the patients would be exposed to more than one procedure. In our systematic review, we cited-but did not specifically study-adverse events. However, all included studies show similar adverse event rates in comparison to single method studies.

Second, we compared EUS-FNA versus ERCP-based tissue sampling and found that EUS-FNA had significantly higher overall accuracy in the diagnosis of malignant biliary stric- tures, with a sensitivity of $76 \%$ versus $58 \%$. EUS-FNA is considered the gold standard for pancreatic lesions, ${ }^{22,38,39}$ and the majority of the included participants had pancreatic lesions. Considering the fact that extraductal lesions cannot be adequately sampled during an ERCP-based tissue sampling from a neighboring stricture unless they invade its lumen, ${ }^{40}$ we also performed a subgroup analysis on just pancreatic lesions. For pancreatic lesions causing biliary strictures, EUS-FNA showed higher diagnostic accuracy compared to ERCP-based tissue sampling, with a sensitivity of $75 \%$ versus $47 \%$, respectively. Additionally, since ERCP-based tissue sampling produces better results for primary biliary lesions (which originate from the biliary epithelium) compared to extraductal lesions, we performed a subgroup analysis on just biliary lesions, and found similar results between both methods, with sensitivity of $71 \%$ for EUS-FNA versus 74\% for ERCP-based tissue sampling.

In our third analysis, we performed a meta-analysis on the results of $\mathrm{BC}$ and $\mathrm{FB}$ during ERCP-based tissue sampling for the included studies. We found that BC was slightly superior to $\mathrm{FB}$, with a sensitivity of $54 \%$ versus $43 \%$. Comparing the individual results of each method to the combination of both, we found that combining methods resulted in a sensitivity of $58 \%$, which is higher than either FB or $\mathrm{BC}$ alone.

Our systematic review and meta-analysis has some limitations. First, there are no randomized controlled trials available in the literature. Additionally, due to the small number of prospective studies that compare same-session procedures, we included two retrospective studies in our analysis. Second, the fact that the majority of included patients have pancreatic lesions may be considered a limitation as this may bias the 
results towards EUS-FNA. However, to minimize this bias, we performed individual analyses of pancreatic and biliary lesions. Third, from the six included studies, two studies ${ }^{3,34}$ used rapid on-site evaluation. This may have impacted our results because rapid on-site evaluation was just performed in the EUS-FNA procedures and not in the ERCP-based tissue sampling procedures, potentially favoring the EUS-FNA group. A meta-analysis showed that rapid on-site evaluation is associated with up to $3.5 \%$ improvement in adequacy rates for EUS-FNA. ${ }^{41}$ Fourth, and probably the most important limitation of this study, is that the included studies do not report enough data for a meta-analysis separating lesion by size (for example, larger or smaller than $2 \mathrm{~cm}$ ). This is notable, as larger lesions can favor EUS-FNA. Fifth, this analysis did not include EUS-fine needle biopsy data which is now more commonly performed with favorable results compared to EUS-FNA. ${ }^{42} \mathrm{Fi}-$ nally, this analysis also does not include advanced cytopathologic analysis such as fluorescence in situ hybridization, which could improve the diagnostic yield. ${ }^{43}$

It's worth noting that EUS-FNA provided better results for masses compared to focal wall thickness or small infiltrative tumors. For these intraductal biliary tumors, there is a place for cholangioscopy, which allows for a biopsy with directed visualization, and can solve the significant problem of indeterminate biliary stricture. ${ }^{44}$ In our systematic review, we do not include any study that performed cholangioscopy. Additionally, the use of EUS-FNA in first-line diagnosis of CCA is considered somewhat controversial given the theoretical implications for peritoneal spread and subsequent liver transplantation candidacy, ${ }^{45}$ although this idea is not universally shared. ${ }^{46,47}$

In summary, our systematic review and meta-analysis revealed that both methods have high specificities and high positive predictive values in diagnosing suspected biliary strictures. However, both have low negative predictive values and therefore, a negative result cannot exclude malignancy. Our results show that a combination of the two methods is the best approach for the tissue diagnosis of a malignant biliary stricture. Nevertheless, the decision to perform concomitant EUS/ERCP is not universal given subtle differences in clinical scenarios. However, single-session EUS/ERCP should be considered whenever possible to maximize diagnostic yield.

\section{CONCLUSIONS}

Same-session EUS-FNA and ERCP-based tissue sampling is superior to either method alone in the diagnosis of suspected malignant biliary strictures. In the individual general analysis, as well as for pancreatic lesions, EUS-FNA is superior to ER-
CP-based tissue sampling. However, for biliary etiologies these methods have similar accuracy. Considering these results, combination sampling should be performed when possible.

\section{Conflicts of Interest}

Marvin Ryou is a consultant for Olympus and Medtronic, Eduardo Guimarães Hourneaux de Moura is a consultant for Boston Scientific and Olympus, Christopher C. Thompson is consultant for Boston Scientific, Olympus and Medtronic. The other authors have no financial conflicts of interest.

\section{Author Contributions}

Conceptualization: Diogo Turiani Hourneax de Moura

Data curation: DTHM, Igor Braga Ribeiro

Formal analysis: Wanderlei Marques Bernardo

Methodology: DTHM, WMB, Eduardo Guimarães Hourneaux de Moura

Project administration: EGHM, WMB

Supervision: EGHM, Christopher C. Thompson

Writing-original draft: DTHM

Writing-review\&editing: Marvin Ryou, CCT

\section{REFERENCES}

1. Korc P, Sherman S. ERCP tissue sampling. Gastrointest Endosc 2016;84:557-571.

2. Moura DTH, de Moura EGH, Matuguma SE, et al. EUS-FNA versus ERCP for tissue diagnosis of suspect malignant biliary strictures: a prospective comparative study. Endosc Int Open 2018;6:E769-E777.

3. Weilert F, Bhat YM, Binmoeller KF, et al. EUS-FNA is superior to ERCP-based tissue sampling in suspected malignant biliary obstruction: results of a prospective, single-blind, comparative study. Gastrointest Endosc 2014;80:97-104.

4. American Society for Gastrointestinal Endoscopy (ASGE) Standards of Practice Committee, Anderson MA, Appalaneni V, et al. The role of endoscopy in the evaluation and treatment of patients with biliary neoplasia. Gastrointest Endosc 2013;77:167-174.

5. Rösch T, Hofrichter K, Frimberger E, et al. ERCP or EUS for tissue diagnosis of biliary strictures? A prospective comparative study. Gastrointest Endosc 2004;60:390-396.

6. Oppong K, Raine D, Nayar M, Wadehra V, Ramakrishnan S, Charnley RM. EUS-FNA versus biliary brushings and assessment of simultaneous performance in jaundiced patients with suspected malignant obstruction. JOP 2010;11:560-567.

7. Butturini G, Stocken DD, Wente MN, et al. Influence of resection margins and treatment on survival in patients with pancreatic cancer: meta-analysis of randomized controlled trials. Arch Surg 2008;143:7583; discussion 83 .

8. Mansfield SD, Barakat O, Charnley RM, et al. Management of hilar cholangiocarcinoma in the North of England: pathology, treatment, and outcome. World J Gastroenterol 2005;11:7625-7630.

9. Jo JH, Cho CM, Jun JH, et al. Same-session endoscopic ultrasound-guided fine needle aspiration and endoscopic retrograde cholangiopancreatography-based tissue sampling in suspected malignant biliary obstruction: a multicenter experience. J Gastroenterol Hepatol 2019;34:799-805.

10. Jailwala J, Fogel EL, Sherman S, et al. Triple-tissue sampling at ERCP in malignant biliary obstruction. Gastrointest Endosc 2000;51(4 Pt 1):383390.

11. Shieh FK, Luong-Player A, Khara HS, et al. Improved endoscopic retrograde cholangiopancreatography brush increases diagnostic yield of malignant biliary strictures. World J Gastrointest Endosc 2014;6:312317. 
12. Ponchon T, Gagnon P, Berger F, et al. Value of endobiliary brush cytology and biopsies for the diagnosis of malignant bile duct stenosis: results of a prospective study. Gastrointest Endosc 1995;42:565-572.

13. Pugliese V, Conio M, Nicolò G, Saccomanno S, Gatteschi B. Endoscopic retrograde forceps biopsy and brush cytology of biliary strictures: a prospective study. Gastrointest Endosc 1995;42:520-526.

14. Draganov PV, Chauhan S, Wagh MS, et al. Diagnostic accuracy of conventional and cholangioscopy-guided sampling of indeterminate biliary lesions at the time of ERCP: a prospective, long-term follow-up study. Gastrointest Endosc 2012;75:347-353.

15. Glasbrenner B, Ardan M, Boeck W, Preclik G, Möller P, Adler G. Prospective evaluation of brush cytology of biliary strictures during endoscopic retrograde cholangiopancreatography. Endoscopy 1999;31:712-717.

16. Sugiyama M, Atomi Y, Wada N, Kuroda A, Muto T. Endoscopic transpapillary bile duct biopsy without sphincterotomy for diagnosing biliary strictures: a prospective comparative study with bile and brush cytology. Am J Gastroenterol 1996;91:465-467.

17. Farrell RJ, Jain AK, Brandwein SL, Wang H, Chuttani R, Pleskow DK. The combination of stricture dilation, endoscopic needle aspiration, and biliary brushings significantly improves diagnostic yield from malignant bile duct strictures. Gastrointest Endosc 2001;54:587-594.

18. Wiersema M, Lehman G, Hawes R. Improvement of diagnostic yield of brush cytology in malignant strictures by the use of supplemental tissue sampling technique. Gastrointest Endosc 1992;35:265A.

19. Singh H, Siddiqui AA. Endosonographic workup and preoperative biliary drainage for pancreatic cancer. Semin Oncol 2015;42:59-69.

20. Harinck F, Konings IC, Kluijt I, et al. A multicentre comparative prospective blinded analysis of EUS and MRI for screening of pancreatic cancer in high-risk individuals. Gut 2016;65:1505-1513.

21. Dewitt J, Devereaux BM, Lehman GA, Sherman S, Imperiale TF. Comparison of endoscopic ultrasound and computed tomography for the preoperative evaluation of pancreatic cancer: a systematic review. Clin Gastroenterol Hepatol 2006;4:717-725; quiz 664.

22. Guedes HG, Moura DTH, Duarte RB, et al. A comparison of the efficiency of $22 \mathrm{G}$ versus $25 \mathrm{G}$ needles in EUS-FNA for solid pancreatic mass assessment: a systematic review and meta-analysis. Clinics (Sao Paulo) 2018;73:e261.

23. De Moura DT, Chacon DA, Tanigawa R, et al. Pancreatic metastases from ocular malignant melanoma: the use of endoscopic ultrasound-guided fine-needle aspiration to establish a definitive cytologic diagnosis: a case report. J Med Case Rep 2016;10:332.

24. De Moura DTH, Moura EGH, Bernardo WM, et al. Endoscopic retrograde cholangiopancreatography versus endoscopic ultrasound for tissue diagnosis of malignant biliary stricture: systematic review and meta-analysis. Endosc Ultrasound 2018;7:10-19.

25. Wang W, Shpaner A, Krishna SG, et al. Use of EUS-FNA in diagnosing pancreatic neoplasm without a definitive mass on CT. Gastrointest Endosc 2013;78:73-80.

26. Mohamadnejad M, DeWitt JM, Sherman S, et al. Role of EUS for preoperative evaluation of cholangiocarcinoma: a large single-center experience. Gastrointest Endosc 2011;73:71-78.

27. Fritscher-Ravens A, Broering DC, Knoefel WT, et al. EUS-guided fine-needle aspiration of suspected hilar cholangiocarcinoma in potentially operable patients with negative brush cytology. Am J Gastroenterol 2004;99:45-51.

28. Eloubeidi MA, Chen VK, Jhala NC, et al. Endoscopic ultrasound-guided fine needle aspiration biopsy of suspected cholangiocarcinoma. Clin Gastroenterol Hepatol 2004;2:209-213.

29. DeWitt J, Misra VL, Leblanc JK, McHenry L, Sherman S. EUS-guided FNA of proximal biliary strictures after negative ERCP brush cytology results. Gastrointest Endosc 2006;64:325-333.

30. Liberati A, Altman DG, Tetzlaff J, et al. The PRISMA statement for reporting systematic reviews and meta-analyses of studies that evaluate health care interventions: explanation and elaboration. Ann Intern Med 2009;151:W65-W94.

31. Moher D, Liberati A, Tetzlaff J, Altman DG. Preferred reporting items for systematic reviews and meta-analyses: the PRISMA statement. PLoS Med 2009;6:e1000097.

32. Whiting PF, Rutjes AW, Westwood ME, et al. QUADAS-2: a revised tool for the quality assessment of diagnostic accuracy studies. Ann Intern Med 2011;155:529-536.

33. Centre for Evidence-Based Medicine. CATMaker and EBM calculators [Internet]. Oxford: CEBM; c2018 [cited 2018 Dec 7]. Available from: https://www.cebm.net/2014/06/catmaker-ebm-calculators/.

34. Novis M, Ardengh JC, Libera ED, et al. [Prospective comparative study of ERCP brush cytology and EUS-FNA for the differential diagnosis of biliary strictures]. Rev Col Bras Cir 2010;37:190-198.

35. Prat F. Suspected malignant biliary strictures: from inside out or outside in? Endosc Int Open 2018;6:E778-E779.

36. Navaneethan U, Njei B, Lourdusamy V, Konjeti R, Vargo JJ, Parsi MA. Comparative effectiveness of biliary brush cytology and intraductal biopsy for detection of malignant biliary strictures: a systematic review and meta-analysis. Gastrointest Endosc 2015;81:168-176.

37. Naitoh I, Nakazawa T, Kato A, et al. Predictive factors for positive diagnosis of malignant biliary strictures by transpapillary brush cytology and forceps biopsy. J Dig Dis 2016;17:44-51.

38. De Moura DTH, Coronel M, Chacon DA, et al. Primary adenosquamous cell carcinoma of the pancreas: the use of endoscopic ultrasound guided - fine needle aspiration to establish a definitive cytologic diagnosis. Rev Gastroenterol Peru 2017;37:370-373.

39. De Moura DTH, Coronel M, Ribeiro IB, et al. The importance of endoscopic ultrasound fine-needle aspiration in the diagnosis of solid pseudopapillary tumor of the pancreas: two case reports. J Med Case Rep 2018;12:107.

40. Banales JM, Cardinale V, Carpino G, et al. Expert consensus document: cholangiocarcinoma: current knowledge and future perspectives consensus statement from the European Network for the Study of Cholangiocarcinoma (ENS-CCA). Nat Rev Gastroenterol Hepatol 2016;13:261280.

41. Matynia AP, Schmidt RL, Barraza G, Layfield LJ, Siddiqui AA, Adler DG. Impact of rapid on-site evaluation on the adequacy of endoscopic-ultrasound guided fine-needle aspiration of solid pancreatic lesions: a systematic review and meta-analysis. J Gastroenterol Hepatol 2014;29:697-705

42. Bang JY, Kirtane S, Krall K, et al. In memoriam: fine-needle aspiration, birth: fine-needle biopsy: the changing trend in endoscopic ultrasound-guided tissue acquisition. Dig Endosc 2019;31:197-202.

43. Brooks C, Gausman V, Kokoy-Mondragon C, et al. Role of fluorescent in situ hybridization, cholangioscopic biopsies, and EUS-FNA in the evaluation of biliary strictures. Dig Dis Sci 2018;63:636-644.

44. Navaneethan U, Hasan MK, Lourdusamy V, Njei B, Varadarajulu S, Hawes RH. Single-operator cholangioscopy and targeted biopsies in the diagnosis of indeterminate biliary strictures: a systematic review. Gastrointest Endosc 2015;82:608-614.e2.

45. Heimbach JK, Sanchez W, Rosen CB, Gores GJ. Trans-peritoneal fine needle aspiration biopsy of hilar cholangiocarcinoma is associated with disease dissemination. HPB (Oxford) 2011;13:356-360.

46. El Chafic AH, Dewitt J, Leblanc JK, et al. Impact of preoperative endoscopic ultrasound-guided fine needle aspiration on postoperative recurrence and survival in cholangiocarcinoma patients. Endoscopy 2013;45:883-889.

47. Onda S, Ogura T, Kurisu Y, et al. EUS-guided FNA for biliary disease as first-line modality to obtain histological evidence. Therap Adv Gastroenterol 2016;9:302-312. 